\section{Claire L. Felbinger}

Claire L. Felbinger passed away suddenly at her home on Wednesday, May 28 , due to a complication from multiple sclerosis (MS). At the time of her death, she had been employed at the Japan International Transport Institute.

Claire received her $\mathrm{Ph} . \mathrm{D}$. in public administration in 1986 from the University of Wisconsin-Milwaukee. Claire taught public administration and program evaluation. She had a distinguished record of research in academia and in think tanks. She was among the first to bring the field of public administration and management to urban infrastructure.

She taught at Northern Illinois University, 1985-1988; she was assistant and associate professor at Cleveland State University, 1988-1998; and associate professor and chair, the department of public administration and policy at American University, 1998-2002. At Cleveland State, Claire was interim director of The Urban Center's Public Works Management Program, which provided management and technical assistance to regional local governments, 1988-1990. She was senior program officer, Transportation Research Board of the National Academies, 2002-2005, and senior research associate, Japan International Transport Institute, 2006 until her death.

Her scholarly record includes six coauthored books, 20 book chapters, and 13 articles in refereed journals. She was editor of Public Works Management and Policy, Sage Publications, 1995-2006.

Among her recent publications are Outstanding Women in Public Administration, edited with Wendy Haynes (M.E. Sharpe, 2004); Public Program Evaluation: A Statistical Guide, with Laura Langbein (M.E. Sharpe, 2006); and Profiles of Outstanding Women in Public Administration, edited with Wendy Haynes (APSA, 2006). She co-organized two published symposia: "Emerging Concepts in Public Administration," with Marc Holzer, and "Public Works Management in Transformation: Challenges to the State and Public Management," also with Marc Holzer. With spouse Richard D. Bingham, she was co-author of both editions of Evaluation in Practice: A Methodological Approach (Chatham House, 2002).

We in the department of public administration and policy at American University hired Claire Felbinger as our department chair in 1998. As it turned out, we not only got a chair, a teacher, and a scholar; we also got a publicspirited manager. At the time Claire was hired, none of us wanted to direct the self-study process for our upcoming NASPAA accreditation review, but Claire was willing. Three of our degree programs were eligible for accreditation-a traditional and executive MPA and an MPP. Claire thought she could write one report for all three degree programs, but the reviewing board ruled that each degree needed a separate report. By the end of Claire's second year as chair, the faculty had adopted all curricular changes, including the structure of concentrations and the initiation of two new concentrations (and the new courses to support those concentrations). Her leadership skills were evident as she guided the writing of the NASPAA self-study for reaccreditation of the traditional and executive MPA and programs as well as the initial accreditation of the MPP program during her second year.

Claire wound up writing three very large self-study reports. In 2001, we became the first department in the nation to have three NASPAA-accredited degree programs.

In 2004, Claire was diagnosed with MS. She faced the disease with grace and aplomb. We remember Claire as a teacher and scholar of public administration who herself was a skilled administrator, demonstrating leadership along with political wisdom, a large dose of humor, and a smile for everyone, eliciting trust from all. She was also an extraordinary mentor to her colleagues, students, and friends.

Claire is survived by her husband Richard Bingham, her mother, her brother, two stepchildren, and 26 step grandchildren. In lieu of flowers, the family requests a donation to the $\mathrm{Na}$ tional Multiple Sclerosis Society (900 S. Broadway, $2^{\text {nd }}$ floor, Denver, CO 80209) in Claire's name.

Laura Langbein American University Karen O'Connor American University

\section{Harlan Hahn}

Harlan D. Hahn, activist and leading authority on disability rights, and a faculty member in USC College for 35 years, has died. He was 68.
Hahn, professor of political science specializing in American and urban politics, died April 23 in his Santa Monica home, said his only child, Emily Hahn.

"My dad had a great passion for helping the disadvantaged," Hahn, 29, of Irvine, said. "He cared about people. $\mathrm{He}$ was an amazingly smart, smart man. But the funny thing was, he didn't think he was smart."

Hahn, who had a joint appointment in the Keck School of Medicine of USC as a professor of psychiatry and behavioral science, earned his masters and doctorate at Harvard University and authored or co-authored about a dozen books. They included Pulitzer Prize-nominated Ghetto Revolts: The Politics of Violence in American Cities (The Macmillan Co., 1973), Disabled Persons and Earthquake Hazards (University of Colorado Institute of Behavioral Science, 1988), and Urban America and Its Police: From the Postcolonial Era through the 1960s (The University Press of Colorado, 2003).

He wrote hundreds of articles and editorials about heath politics and policies, criminal justice policy, and urban issues and politics for professional journals, books, and major metropolitan newspapers such as the Los Angeles Times.

Hahn left USC in 2007. He had been writing his memoir when he died.

"Harlan Hahn's death is an enormous loss because of his international reputation on disability research and his activism," said Ann Crigler, chair and professor of political science in the college. "He was also a very well-known researcher in American and urban politics in general. He was one of our department's most prolific, highly-cited and distinguished professors."

Gelya Frank, professor of anthropology in the college, and professor of occupational science and occupational therapy, recalled arriving at USC in the early 1980s, when Hahn and junior faculty members were developing the university's first disability studies program.

At that time Hahn was also involved in a famous right-to-die case in which quadriplegic Elizabeth Bouvia had sued a California hospital refusing her request to starve to death. Hahn had filed an amicus brief with the California Supreme Court, arguing against the woman's wish to die and urging society to better support the disabled. Bouvia eventually lost the case and later decided she wanted to live. 
"I recognized that what Harlan was doing was exciting and important," Frank said. "He was on the front lines of the shift in political thinking about the disabled. Rather than disability as a private medical matter, he believed in treating the disabled as a minority group that deserved rights."

Hahn pushed for the U.S. Rehabilitation Act of 1973, prohibiting discrimination based on disabilities, and the Americans with Disabilities Act of 1990, a wider-ranging civil rights law prohibiting discrimination based on disabilities, his friends said.

"We wouldn't have these laws without people like Harlan," Frank said. "We have to see Harlan Hahn as one of the major figures in the disability rights movement."

Born July 9, 1939, in Osage, Iowa, Harlan Hahn had an identical twin who died at birth and he grew up as an only child, Emily Hahn said. His parents were teachers. At age five he contracted polio and spent the next six years in and out of hospitals. He entered school at 11 and used a wheelchair most of his life.

Before entering Harvard, Hahn earned his bachelors magna cum laude at St. Olaf College in Minnesota. He was a perpetual student, earning two additional masters degrees - an MS in 1982 from California State University, Los Angeles, and an MPH in 2004 from UCLA.

"Education was really, really important to him," said Emily Hahn, who is earning her masters degree in psychology at California State University, Long Beach. "He tried to do the best in helping people who didn't have access to an education or to health care get opportunities. He wanted people in disadvantaged situations to have a voice."

At times Hahn's activism hit closer to home. In 1998 Hahn filed a suit against USC, claiming that the University Park campus had numerous physical barriers preventing disabled people from equal access to structures. As a result of a settlement in the case, the university has steadily increased its budget for removing such barriers.

"My dad was a real fireball," Emily Hahn said. "If I accomplish half of what my dad did in his life, I'll be happy."

Judy Garner, associate provost for faculty development, created a stem cell research ethics course with Hahn.

"I appreciated working with him," said Garner, an associate professor in the Keck School. "He broadened my perspective on how stem cell work has become a political force, and how the development of this research area has resulted in conversations about ethical dilemmas that really need airing."
Longtime friend Gerald Caiden, professor in the USC School of Policy, Planning, and Development, remembered Hahn as a complex and tireless man whose "mind bubbled over with ideas."

"When I heard of his death, I immediately felt a loss," Caiden said. "Never again would I hear his unmistakable voice, 'Ah, Gerald, how nice of you to phone. Listen, I have this new idea I want to try on you ....",

A memorial for Hahn took place May 15 inside the craft room in Joslyn Park. In lieu of flowers, donations may go to the American Disability Association.

Pamela J. Johnson University of Southern California

\section{Note}

* The information in this article is courtesy of USC News. The original version can be found at www.usc.edu/uscnews/stories/15214.html.

\section{Theodore H. McNelly}

Theodore H. McNelly, professor emeritus, department of government and politics at the University of Maryland, College Park, passed away in February 2008 at the age of 88. Professor Emeritus McNelly was born on December 27, 1919, and received his Ph.D. in 1952 at Columbia University. McNelly joined the faculty in the department of government and politics at Maryland in the fall of 1953 as a lecturer, was promoted to professor in 1967, and retired in 1991.

McNelly studied politics and government in Japan. His most recent publication "Witness to the Twentieth Century," a personal biography of his life, was published in 2005. During World War II, McNelly served as a cryptanalyst and linguist in the U.S. Signal Intelligence Service and later as an analyst in General MacArthur's Civil Intelligence Section in Tokyo. He has authored numerous articles and books including The Origins of Japan's Democratic Constitution. He analyzed the developments that he observed in postwar England, France, Germany, Japan, and Korea and described his career as an author and college professor.

\section{E. Cissy Abu Rumman University of Maryland, College Park}

\section{Trudi C. Miller}

Trudi C. Miller died on September 30, 2003, after a brief illness. After earning a BA in English from Cornell University and a Ph.D. in political science from the University of North Carolina at Chapel Hill, she spent most of her career at the National Science Foundation. After a brief stay at the State University of New York at Buffalo, she moved to NSF, where she rose to be the program director for the Decision, Risk and Management Division of Social and Economic Science.

She won three prestigious awards in our profession. In 1989/90 Trudi won the Marshall E. Dimock Award for the best lead article in the Public Administration Review for "The Operation of Democratic Institutions.” In 1989 she won the Policy Studies Organization's award for the best paper presented at the American Political Science Association Annual Meeting for "Designing Social Structures: A Scientific Perspective." And in 1981 she won the Franklin L. Burdette Pi Sigma Alpha Award for the best paper at the APSA meeting for "Toward a Normative Dynamic Model for Educational Equity." In addition, she published many articles in books and refereed journals, including Politics and the Life Sciences, Journal of Theoretical Politics, IEEE Transactions on Systems, Man and Cybernetics, and The American Political Science Review.

Trudi Miller was a committed scholar who kept learning and writing until the end. She was always inclined to question and challenge conventional academic wisdom. A long-term project had been a book manuscript entitled Democracy, Markets, and Money, which she completed shortly before her death.

Trudi took great joy in family and friends. She is survived by her beloved husband, Ettore (Jim) Infante, and his family. She took care of her parents and her mother-in-law until they died, and Jim took care of her in her illness. Trudi Miller is greatly missed.

\section{William R. Keech Carnegie Mellon University}

\section{William R. Nelson}

Dr. William R. Nelson, Lt. Col. USAF (ret.), passed away on June 30, 2008, at Rockingham Memorial Hospital in Harrisonburg, VA. Dr. Nelson was born February 5, 1924, in Colton, California. He was the son of the late William Gunther and Vera Maughan Nelson.

Dr. Nelson served with the $20^{\text {th }}$ Air Force, $793^{\text {rd }}$ Squadron and 468th Bomb Group and flew 35 bombing missions as a navigator over Japan. He received a law degree at the University of Utah after the war. He then returned to the Air Force and served in various posts 